\title{
A FORMAÇÃO DOCENTE EM LABORATÓRIOS UNIVERSITÁRIOS DE ENSINO DE HISTÓRIA ATRAVÉS DA PRODUÇÃO DE MATERIAIS DIDÁTICOS: A EXPERIÊNCIA DO LEHRB-UFRB ${ }^{1}$
}

\section{Leandro Antonio de Almeida ${ }^{2}$}

Resumo: O objetivo desse trabalho é analisar uma experiência de formação de professores de História em laboratórios universitários de ensino de História. Espaços institucionais voltados ao ensino, à pesquisa e extensão universitária nos cursos de licenciatura, seu número aumentou bastante nos anos 2000, motivando artigos e teses sobre esse tema. No artigo vamos nos deter nas atividades do Laboratório de Ensino de História do Recôncavo da Bahia (LEHRB), da Universidade Federal do Recôncavo da Bahia (UFRB). Primeiro abordaremos a formação, atividades e projetos entre 2009 e 2017, e como condicionaram percepções sobre esse espaço, para então expor e analisar três experiências de produção de materiais didáticos. Complexa e interdisciplinar, tais experiências permitiram aos professes e graduandos exercitarem seus saberes históricos e pedagógicos, lidar com saberes distantes da formação como informática e artes visuais, e, sobretudo, exercer sua autonomia docente ao definir e conduzir o processo de elaboração.

Palavras-chave: Laboratório de Ensino de História. Materiais didáticos. Formação de professores.

\section{TEACHING TRAINING AT HISTORY TEACHING UNIVERSITY LABORATORIES THROUGH THE COURSEWARE MAKING: THE LEHRB- UFRB EXPERIENCE}

Abstract: The main goal of this paper is to analyse a History Teacher formation experience at Universitary History Teaching Labs. Institutional spaces addressed to undergraduate teaching, research and university extension in licentiate degree courses, in 2000s its number has increased, motivating papers and thesis on this subjetct. In this paper we focus on Reconcavo da Bahia History Teaching Lab (LEHRB)'s activities, at Recôncavo da Bahia Federal University (UFRB). Firstly we will expose Lehrb's beginnings, activities and projetcts between 2009 and 2017, and how thew conditionated perceptions about this space, and then analyse three experiences of making teaching materials. Complex and interdisciplinary, such experiences propitiated teachers and undergraduate students to exercise their historical and pedagogical knowledge, to deal with knowledge far from their formation courses like computer and visual arts, and, above all, to exercise their teaching autonomy in defining and leading the process.

Keywords: Teaching History Lab. Teaching materials. Teaching formation.

\footnotetext{
1 Versões preliminares deste trabalho foram apresentados oralmente nos seguintes eventos: Mesa "Laboratórios de pesquisas em universidades brasileiras: objetos, abordagens e novos campos de pesquisa" no VII Encontro de História da UNEB - Campus VI - Caetité, em maio de 2016; Mesa "Laboratórios de Ensino de História como Espaços de Formação Inicial e Continuada de Docentes", do VIII Encontro Estadual de História, promovido pela ANPUH-BA em novembro de 2016. Simpósio Temático 08 "Didática da História: investigações empíricas e experimentos no ensinar-aprender os saberes históricos" do IX Encontro Estadual de História, promovido pela ANPUH-BA em setembro de 2018.

2 Doutor em História Social (USP), professor do curso de licenciatura em História e do Mestrado Profissional em História da África, da Diáspora e dos Povos Indígenas, situados no do CAHL-UFRB, Cachoeira-BA. Integrante do Grupo de Pesquisa "Humor e História", coordenado por Elias Thomé Saliba na USP. Líder do grupo de pesquisa "Roda de Histórias - Ensino de História no Recôncavo da Bahia". Email: leandroaalmeida@hotmail.com.
} 


\section{L'ENSEIGNEMENT DE LA FORMATION EN HISTOIRE L'ENSEIGNEMENT DANS LES LABORATOIRES UNIVERSITAIRES PAR LA RÉALISATION DE DIDACTICIELS: L'EXPÉRIENCE DU LEHRB-UFRB}

Résumé: Le but principal de cet article est d'analyser une expérience de formation d'un professeur d'histoire dans les laboratoires universitaires d'enseignement de l'histoire. Les espaces institutionnels destinés à l'enseignement de premier cycle, à la recherche et à l'extension universitaire dans les cours de licence, ont vu leur nombre augmenter dans les années 2000, motivant des articles et des thèses sur ce sujet. Dans cet article, nous nous concentrons sur les activités du Reconcavo da Bahia History Teaching Lab (LEHRB), à l'Université fédérale du Recôncavo da Bahia (UFRB). Dans un premier temps, nous exposerons les débuts, les activités et les projets du LEHRB entre 2009 et 2017, et comment ils ont conditionné les perceptions de cet espace, puis nous analyserons trois expériences de fabrication de matériel pédagogique. Complexes et interdisciplinaires, ces expériences ont incité les enseignants et les étudiants de premier cycle à exercer leurs connaissances historiques et pédagogiques, à traiter des connaissances éloignées de leurs cours de formation comme l'informatique et les arts visuels et, surtout, à exercer leur autonomie d'enseignement pour définir et diriger le processus.

Mots-clés: Enseignement du laboratoire d'histoire. Matériel pédagogique. Formation à l'enseignement.

\section{FORMACIÓN DOCENTE EN LABORATORIOS UNIVERSITARIOS DE LA ENSEÑANZA DE HISTORIA MEDIANTE LA PRODUCCIÓN DE MATERIALES DIDÁCTICOS: LA EXPERIENCIA DEL LEHRB-UFRB}

Resumen: El objetivo de este trabajo es analizar una experiencia de formación de profesores de Historia en los laboratorios universitarios de enseñanza de la Historia. Espacios institucionales enfocados a la docencia, la investigación y la extensión universitaria en las carreras de grado, su número aumentó considerablemente en la década del 2000, motivando artículos y tesis sobre este tema. En el artículo nos centraremos en las actividades del Laboratorio de Enseñanza de la Historia del Recôncavo da Bahia (LEHRB), de la Universidad Federal de Recôncavo da Bahia (UFRB). Primero, abordaremos las capacitaciones, actividades y proyectos entre 2009 y 2017, y cómo condicionaron las percepciones sobre este espacio, para luego exponer y analizar tres experiencias en la producción de materiales didácticos. Complejas e interdisciplinarias, estas experiencias permitieron a profesores y estudiantes de pregrado ejercitar sus conocimientos históricos y pedagógicos, abordar conocimientos lejanos a la formación como la informática y las artes visuales y, sobre todo, ejercitar su autonomía docente a la hora de definir y conducir el proceso de elaboración.

Palabras-clave: Laboratorio de Enseñanza de la Historia. Materiales de enseñanza. Formación de profesores.

\section{Introdução}

Ao escutarmos a palavra "laboratório", provavelmente pensamos nos homens e mulheres de jaleco branco, com óculos negros pesados, manipulando substâncias coloridas em tubos de ensaio, balões e outros frascos de vidro. Ou observando lâminas com seres vivos em algum microscópio, ou ainda observando aparelhos metálicos de grandes proporções cuja funcionalidade desconhecemos. São imagens desse tipo que aparecem nos buscadores quando se digita a palavra em português e em outras línguas. Mobilizando o prestígio que as ciências experimentais ganharam no Ocidente nos 
últimos cento e cinquenta anos, são difundidas pelos telejornais, filmes hollywoodianos e propagandas de laboratórios de análises clínicas e universidades privadas no Brasil. Arraigadas no imaginário, tais representações elidem a existência de laboratórios de Ciências Humanas ou, mais ainda, Laboratórios de História. Afinal, os historiadores não têm acesso direto a realidades passadas, e os procedimentos básicos da disciplina são relativamente desconhecidos dos leigos. Uma amostra do desconhecimento e preconceitos ainda atuais emergiu quando a Universidade Estadual de Londrina (UEL) projetou um dos primeiros Laboratórios de Ensino de História do país, no início dos anos 1990. Nas palavras de um dos idealizadores:

[...] a palavra Laboratório foi inclusive uma curiosidade porque a Universidade não queria registrar nosso projeto como Laboratório e sim como Núcleo, porque uma parte da Universidade é formada pelas chamadas Ciências Duras e eles entendem Laboratório como espaço de experimentação, e eu estive na reunião e perguntei: "porque vocês acham que só a ciência de vocês é experimental e a nossa ciência não tem possibilidade de sê-la porque o passado tá passado? (...), o laboratório nosso é um laboratório de reflexão do passado, não são os vírus, não são os equipamentos que vocês usam, mas são a nossa epistemologia, nossas regras metodológicas". Aí, é claro que nós vencemos o debate e ficou registrado como Laboratório de Ensino de História, mas ainda assim, no projeto em que registrava o LABHIS, estava lá "Núcleo Laboratório". Ainda houve resistência, mas nós nunca consideramos isso. (Carlos Apud MARIN, 2013, p. 126)

A despeito do estranhamento, não restrito a essa universidade (PERLI; JESUS, 2015, p. 214), tais "espaços de trabalho" especializados em produzir e divulgar História existem nas várias universidades brasileiras, visando dar conta dos variados temas e linhas historiográficas. Neste artigo, o foco são os Laboratórios de Ensino da História, entendidos como espaços institucionais dedicados ao trabalho e pesquisa sobre a didatização do conhecimento histórico ${ }^{3}$. Este sentido se distingue de outros usos do termo no Brasil, como a nomenclatura dos Grupos de Pesquisa nessa área que, segundo as regras atuais do $\mathrm{CNPq}$, necessariamente são interinstitucionais. Outro significado denota os componentes curriculares nos cursos de licenciatura com carga horária prática de quatrocentas horas prevista pela legislação, desde a Resolução CNE/CP n. 2/2002 4 .

\footnotetext{
${ }^{3}$ Mesmo levando em conta a (desejável) existência de laboratórios escolares de Ensino de História, a exemplo do IFBaiano de Catu (NEHMJr), consideraremos apenas aqueles fundados e atuantes nas Instituições de Ensino Superior.

${ }^{4}$ A questão da definição de Laboratório de Ensino de História foi objeto do debate na mesa "Laboratórios de Ensino de História como Espaços de Formação Inicial e Continuada de Docentes", do VIII Encontro Estadual de História, promovido pela ANPUH-BA. Agradeço os integrantes Profa. Dra. Edinalva Padre Aguiar (UESB), Profa. Dra. Cristiana Ferreira Lyrio Ximenes (UNEB), bem como aos debatedores, o prof. Dr. Fernando Penna (UFF) e profa Dra Maria Cristina Dantas Pina (UESB). A responsabilidade
} 
Apesar de tal distinção, o trabalho com a didatização do conhecimento histórico nos Laboratórios de Ensino de História pode se integrar e dar suporte, sem necessariamente se confundir com as dimensões de pesquisa, básica e/ou aplicada; extensão, escolar ou geral; e ensino, de graduação e pós-graduação. Geralmente tais espaços também contam com infraestrutura como equipamentos, materiais de consumo e permanentes, e até mesmo acervos diversos. Sua organização, objetivos e abrangência das atividades é determinada pelas condições de cada instituição.

Marilu Favarin Marin (2013, p. 125), na primeira tese sobre o tema no país, mostra como os primeiros Laboratórios de Ensino de História foram criados em universidades públicas durante a redemocratização do país, nos anos 1980 e 1990, visando "estudos da formação inicial e continuada de professores, com a intenção de recuperar a relação teoria e prática nessa formação" e superação de modelos prescritivos rumo a uma formação crítica. Em relação aos primeiros Laboratórios, da UEL (LABHIS, 1993), da UFU (LEAH, 1982), da UFSM (LPEH, 1988), a autora aponta que:

[...] foram criados a partir de iniciativas que agregaram tanto a professores do ensino superior como da educação básica, e se constituíram nas suas origens como espaços de compartilhamento de dúvidas e experiências de professores sobre o ensino da história. As ações desencadeadas a partir daí carregaram um caráter predominantemente instrumental, corroborando a ideia de Laboratório como espaço para disponibilização de recursos de apoio ao ensino. (MARIN, 2013, p. 204).

Com a mudança do contexto educacional, boa parte desses laboratórios repensaram suas atuações, enquanto novos Laboratórios, como o LAPEDUH, já apresentavam outra perspectiva:

$\mathrm{Na}$ análise do LAPEDUH/PPGE/UFPR, criado em 2003, foi possível concluir que o Laboratório surge em um contexto histórico educacional marcado por reflexões que objetivam avaliar os avanços na educação no período de transição para a democracia (especialmente décadas de 1980-90). Então sua proposta é diferenciada, especialmente na forma como se relacionam os profissionais do ensino superior e da educação básica - através da colaboração. Percebe-se um claro rompimento com o pensar a educação para a escola, e a progressão para o pensar a educação com os professores que atuam nas escolas. [...] as ações do LAPEDUH tem contribuído para superar o preconceito em relação ao professor da escola básica, preconceito que o mantém limitado a uma condição de simples repetidor de produções de outros. Nesse sentido, o trabalho no LAPEDUH está fortalecendo um novo significado ao professor da escola básica na medida em 
que o vê como um profissional apto a debater, investigar e produzir. (MARIN, 2013, p. 205)

No século XXI, o número de Laboratórios de Ensino de História aumentou nas duas linhas apontadas por Marin ${ }^{5}$, e professores vinculados a esses laboratórios, como os membros do LAPEDIH (UNESP), o LEH (UEL) e os NAEH (UCS) / LHISTE (UFRGS), LABHIS (UFGD) publicaram artigos em revistas especializadas, contando a experiência de formação e atuação (LIA et al., 2015; CAINELLI et ali, 2005; ALVES, 2015; JESUS e PERLI, 2015). Tais artigos se somam ao estudo de Marin no mapeamento e reflexão acadêmica sobre tais laboratórios e permitem ampliar suas constatações. Os Laboratórios de Ensino de História são concebidos como espaços de integração entre teoria e prática na formação de professores, superando essa dicotomia a partir das atividades de ensino, investigação e formação de grupos de pesquisa, bem como extensão feita de maneira presencial e/ou virtual através das páginas da internet.

$\mathrm{Na}$ linha destes autores, neste artigo pretendemos refletir sobre as experiências do Laboratório de Ensino de História do Recôncavo da Bahia (LEHRB), vinculado ao curso de Licenciatura em História e ao Centro de Artes, Humanidades e Letras (CAHL), campus Cachoeira da Universidade Federal do Recôncavo da Bahia (UFRB). O LEHRB surgiu e foca suas atividades a partir das demandas de extensão, às quais se integraram as dimensões de ensino e pesquisa aplicada no Ensino de História. O Laboratório acompanhou essa modalidade de pesquisa que marcou a área de História no país na última década, a qual, na UFRB, também se desdobrou na criação do PIBID em 2013 e do Mestrado Profissional em História da África, da Diáspora e dos Povos Indígenas em 2014. Após descrever a trajetória e ações do Laboratório, detalhando sua relação com diversos setores internos e externos à universidade, forcaremos a pesquisa aplicada destinada à produção de materiais didáticos e sua relação com a formação de professores de História.

\footnotetext{
${ }^{5}$ Numa lista provavelmente incompleta, com os diversos objetivos, ligados ou não a grupos de pesquisa, levantamos, em páginas próprias ou abrigados em sites institucionais, a existência do LABHIS (UEL), LAPEDUH (UFPR), LAPHIS (UNESPAR), LEH (UDESC), NAEH (UCS), LHISTE (UFRGS), LABORHIS (UEG), Laboratório de Ensino de História (UFG), Etrúria (UFMT), LEMAD (USP), CEPEDIH (USP), LAPEDIH (Unesp), Oficina de História (UERJ), LABEPEH (UFMG), LABHIS (UFGD), LAHIS (UFES), LEHIS (Unicentro), LEAH (UFU), LEH (FGV), LEH (UFF), LAHIGE (UESC), LEH (UFPel) e LAPEH (UESB).
} 


\section{Trajetória e Atividades do LEHRB (2010-2017)}

O curso de História da UFRB começou a funcionar no segundo semestre de 2006, e os primeiros concursados da área de Ensino de História assumiram o cargo a partir de agosto de 2009. De imediato, o colegiado demandou a elaboração de um projeto de laboratório, apresentado e aprovado na reunião de 14 de outubro de 2009. Seu objetivo geral era potencializar as ações relacionadas à área de Ensino de História, tornando-se um espaço de suporte ao ensino básico e superior, pesquisa educacional local e nacional, e extensão universitária voltada às escolas e à comunidade em geral. Os objetivos específicos eram armazenar materiais didáticos, apoiar o público-alvo (como docentes, discentes, professores da escola pública e interessados), desenvolver projetos de pesquisa e extensão, promover eventos, manter intercâmbio com laboratórios de ensino de história de outras instituições de ensino superior (ALMEIDA, 2009).

Para concretizar tais objetivos começamos pelo fim. Junto com o professor Sérgio Armando Diniz Guerra Filho, foi feita uma visita técnica ao LAHIGE, Laboratório de Ensino de História e Geografia da UESC, em funcionamento desde 1997 e uma referência na Bahia. A visita recepcionada pela professora Ana Lúcia Côgo ajudou a entender rotinas e requisitos para funcionamento de um Laboratório. Consideramos proveitosos a intensa programação de eventos (oficinas, palestras, cursos) e a coleção de mapas históricos impressos em tamanho pôster, para uso no estágio ou atividades nas escolas. Tal busca de modelos a partir de intercâmbios entre as universidades próximas e sites na internet parece ser recorrente. Um exemplo são os laboratórios situados no Rio Grande do Sul (MULLET et al, 2015, p. 177), os quais tomaram o LEHRB como referência para algumas de suas iniciativas, adequando nossas experiências e práticas à realidade da instituição e do curso. $\mathrm{O}$ acúmulo de experiências justifica estudos mais amplos sobre o tema e a necessidade de um encontro nacional dos Laboratórios para apresentar seus objetivos, práticas, dificuldades e direcionamentos. Um exemplo regional dessa iniciativa ocorreu na mesa "Laboratórios de Ensino de História como Espaços de Formação Inicial e Continuada de Docentes", do VIII Encontro Estadual de História (2016), promovido pela ANPUH-BA em Feira de Santana, onde compartilhamos experiências com colegas da UESB, UEFS e Uneb.

Já na função de coordenador, a partir do início de 2010 empreendemos as primeiras ações para estruturação de um espaço. Em fins de agosto desse ano uma sala 
foi equipada com um computador, impressora, armários, mesas, lousa branca, estantes de ferro e vinte carteiras, o que deixou o espaço em condições de uso. Então teve início a formação e catalogação do acervo, constituído a partir da doação de livros didáticos, paradidáticos, acadêmicos e outros, por docentes e discentes da universidade, professores da região do Recôncavo, um trabalho coletivo que ainda prossegue, e, pontualmente, por editoras como Ática e Moderna. Porém, entre fevereiro de 2012 e maio de 2013 a sala foi usada para armazenar livros de um acervo especial doado à UFRB (Clemente Mariani) e, logo depois, a umidade subterrânea causou mofo nas paredes, tornando-a insalubre. Apenas em agosto de 2014 outra sala foi disponibilizada, com mobília e equipamentos, bem como disponibilização de um servidor técnico em assuntos educacionais. Em outubro desse ano recebeu da diretoria da ANPUH-Ba, presidida por Fabrício Lyrio dos Santos, doação de mais equipamentos e material de consumo, após o apoio ao Encontro Estadual de História, em Cachoeira.

A implicação dos problemas de infraestrutura foi a necessidade de atuar no ambiente virtual e em projetos fora da universidade. Em abril de 2010 o site do Laboratório de Ensino de História do Recôncavo da Bahia foi disponibilizado, atualmente no endereço: https://www3.ufrb.edu.br/lehrb/ - concebido para atuar em três frentes. A primeira era disponibilizar informações institucionais sobre o próprio laboratório, sobre o colegiado de História e sobre a área de Ensino no curso como os Estágios curriculares e PIBID-História, reunidos sob o menu "Licenciatura em História UFRB”. A segunda frente foi fruto de buscas permanentes na internet voltadas ao campo de pesquisa do Ensino de História como legislação, dossiês acadêmicos, revistas especializadas, outros laboratórios e grupos de pesquisa, e blogs individuais de pesquisadores ou professores. Já a terceira frente, "Objetos Educacionais Digitais", procurava subsidiar a prática em sala de aula através de links para materiais em diversas linguagens como fontes digitalizadas, materiais didáticos, mapas, jogos, animações e modelagens, o que diversificava as possibilidades de trabalho docente.

Com tais páginas procurávamos fornecer referenciais que subsidiassem pesquisas e docência na área de Ensino de História, já que os links direcionam para os principais veículos de informação sobre o tema. Através delas o professor ou licenciando tinha canais de acesso para o que há de mais atual na produção acadêmica, oficial e didática, bem como a acervos que disponibilizam fontes históricas. Estavam excluídas das listagens teses e dissertações, que possuem base de dados própria - o Banco de Teses da Capes. Utilizávamos tais links nas aulas da disciplina "Ensino de 
História", nos "Estágios Supervisionados" e na orientação de TCC, seja como suporte à pesquisa temática, seja como apoio pedagógico para construção de aulas. Mas as páginas e listagens de links do site foram desativadas em junho de 2016. Primeiramente foram desativados os links do colegiado do curso e do Subprojeto História do PIBIDUFRB, pois eles elaboraram sites próprios. Segundo, e atualmente única função do site junto com a página do Facebook, buscamos dar maior visibilidade às informações, ações e produções do próprio "Laboratório de Ensino de História do Recôncavo da Bahia". Como os links se tornaram referência para outros laboratórios, pesquisas e discussões no campo do Ensino de História, projeta-se transferi-los para outro site externo:

Figura 1: Página do Laboratório de Ensino de História do Recôncavo da Bahia

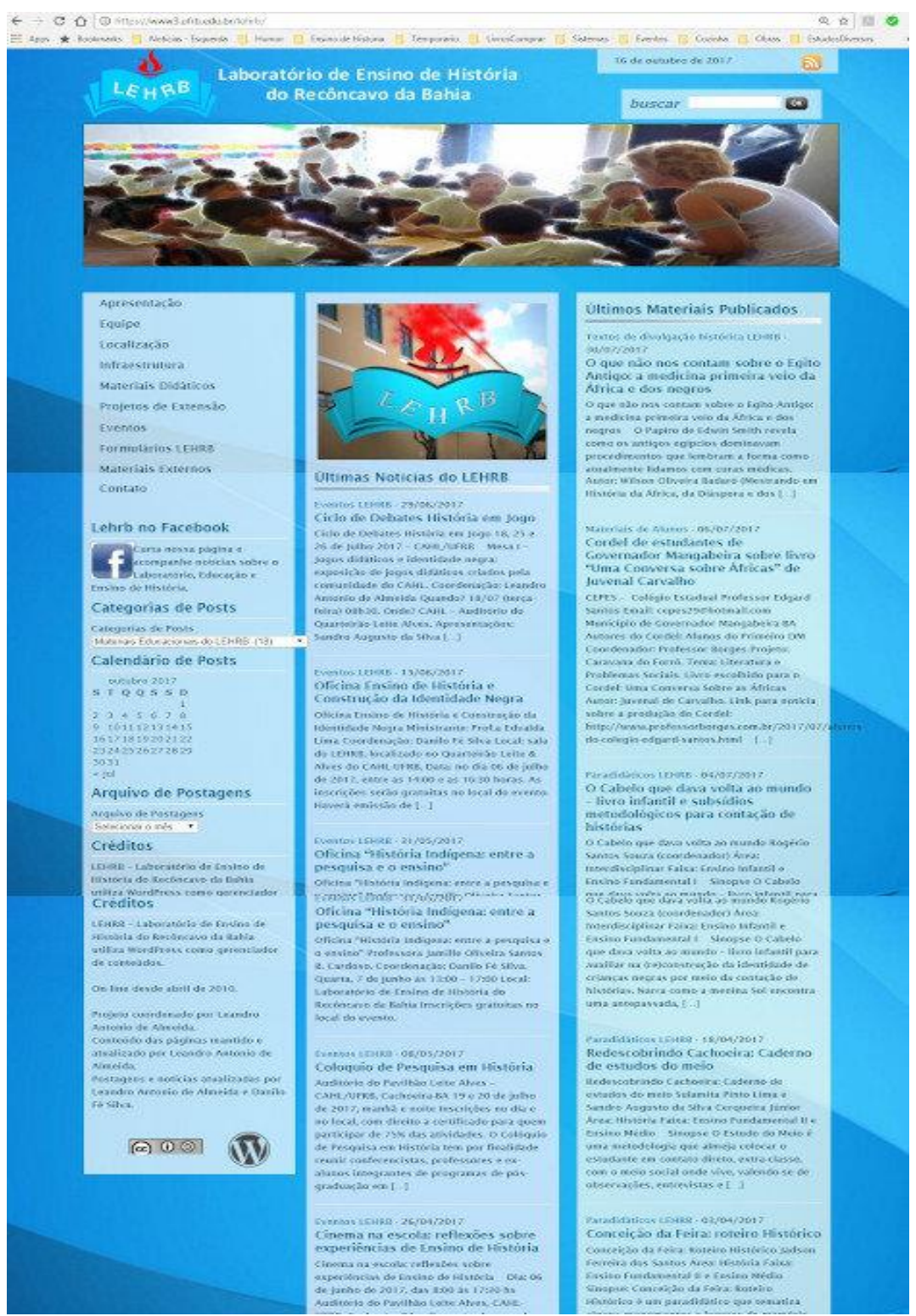

Fonte: Site do LEHRB. Acesso em: out. 2017. 
Os eventos são uma importante forma de o LEHRB se relacionar com o curso, com a comunidade escolar e outros interessados no Recôncavo. Visando ouvir os professores de História da região, o primeiro evento ocorreu em novembro de 2009, o "I Encontro de Ensino de História do Cahl”. Até 2013 os principais eventos eram produto das disciplinas da licenciatura, voltadas à apresentação do resultado de pesquisas de graduandos do semestre, como os cinco "Seminários de Ensino de História".

De outubro de 2015 a julho de 2017, o Laboratório deu um passo além e passou a oferecer cursos e oficinas, ministrados por professores da educação básica, mestrandos e graduandos, voltados à formação continuada de professores e discentes do curso, a exemplo de "Contação de Histórias na Escola", "Ensino de História e Literatura: trabalhando contos afro-brasileiros em sala de aula", "RPG e Ensino de História", "Ensino de História e Jogos Digitais: aspectos teórico-metodológicos para a sala de aula" e "Educação Escolar Quilombola". Paralelo aos cursos, realizou-se eventos sobre temas atuais e polêmicos, como "Base Nacional Comum Curricular: Para onde vai o Ensino de História?", "Debate sobre o Projeto Escola sem Partido" e "Livro Didático: subsídios para a escolha do PNLD 2017”.

Em outra vertente de eventos, em 2016 e 2017 promoveu-se cursos ligados a temas de história e historiografia, com convidados da Bahia e outros estados e países, a exemplo do curso "Estudos de gênero em perspectiva: investigações interdisciplinares", um "Colóquio de Pesquisa em História", coordenados pelo professor Marco Antonio Nunes da Silva, bem como a palestra "O EZLN e o Zapatismo: 30 anos de luta e resistência”, coordenado por Nuno Gonçalves. O Laboratório também apoiou ou coorganizou eventos de História promovidos pelo colegiado do curso e pela ANPUHBA, como o III Encontro de Ensino de História, de 2013, e VII Encontro Regional de História, de 2014.

Como em nenhum dos eventos os palestrantes eram remunerados, contou-se com o trabalho voluntário de todos os envolvidos, egressos, colegas de outras instituições e professores da educação básica, todos interessados em divulgar o seu trabalho. Essa rede de colaboração, aliada à estruturação de um espaço próprio com equipamentos, possibilitou a oferta frequente - uma vez ao mês, pelo menos - de cursos e palestras, uma marca do Laboratório e até esperada pela comunidade interna.

A mesma estruturação possibilitou ao LEHRB realizar, desde 2016, ações de extensão nas escolas públicas do Recôncavo, em parceria com docentes de História. O “Cineclube LEHRB” procurou discutir com estudantes filmes com temáticas ligadas à 
área de história em uma escola de Saubara e outra de Muritiba. Para cada exibição a equipe executora, composta por um técnico em assuntos educacionais e dois bolsistas, preparou uma proposta didática relacionada ao filme "As Cruzadas". Outro projeto, “Roteiros e Vivências no 2 de julho", realizado em parceria com uma escola de Cruz das Almas e mestrandos de História da UFRB, trabalhou o tema da Independência do Brasil na Bahia através de visitas guiadas em Cachoeira, de um jogo de RPG e da participação em um plenária organizada pela professora e seus alunos da educação básica. Por fim, o projeto "Ilê de Memórias", decorrente da oficina "Contação de Histórias na Escola", valeu-se dessa metodologia em uma escola de Maragogipe para que crianças ilustrassem os contos produzidos, visando publicação do material e de um caderno de apoio ao professor.

Além dos projetos, cursos e eventos, o LEHRB, através do seu espaço físico, se propunha a ser um acervo de referência ao disponibilizar materiais de auxílio à pesquisa e à atuação docente no Recôncavo. Os itens bibliográficos são os mais numerosos, com recentes e antigas coleções didáticas de História do Ensino Fundamental I e II, do Ensino Médio e livros paradidáticos, havendo em menor quantidade livros acadêmicos, literários, publicações oficiais e outras. Além disso, há recortes de jornal, fitas VHS, DVD, mapas e jogos, comerciais e produzidos pelos alunos nas disciplinas do curso, sobretudo História Antiga, ministrada por Denis Correa. Todos os materiais do Laboratório são obtidos por doação dos docentes do curso, bem como alunos de história e professores da rede, contando também com doações maiores, como livros didáticos e paradidáticos desde os anos 1930 recebidos do acervo da Antiga Biblioteca Municipal de São Félix, ou coleção da Revista Veja, doada pelo grupo de pesquisa do professor Juvenal Carvalho Conceição. Exceto os relatórios e itens especiais, todos os outros materiais podem ser emprestados aos alunos do curso e professores cadastrados. Geralmente são utilizados pelos docentes universitários em disciplinas de prática como componente curricular que, por exemplo, solicitavam aos graduandos a consulta a determinada temática nas coleções didáticas. Portanto, são importantes materiais de suporte para o ensino de graduação no curso de Licenciatura em História da UFRB, mantidos e alimentados por uma rede de doação.

Parte dos materiais tem potencial de se tornar fontes de pesquisa sobre Ensino de História e Educação no Recôncavo, obtido através de parceria com docentes das disciplinas de graduação ligadas à licenciatura. Há material fruto da parceria feita com a disciplina optativa ministrada pela professora Marta Lícia Brito Teles de Jesus, 
intitulada "História, Memória e Oralidade", ofertada nos semestres 2014.1 e 2014.2. Da parceria derivou um projeto que integrava ensino, pesquisa e extensão, com o objetivo de disponibilizar entrevistas com professores do Recôncavo como fontes para História da Educação, as quais foram gravadas em áudio durante o semestre letivo, armazenada nesse espaço e disponibilizadas no site do Laboratório. Outras fontes, mais numerosas, provém dos relatórios produzidos pelos alunos e cedidos por docentes das três disciplinas de Estágio Supervisionado desde 2010. Tais relatórios não apenas são úteis como modelos para estagiários dos semestres seguintes, como são fontes sobre as próprias escolas em que irão realizar a observação ou regência. Mais recentemente, por reunirem informações sobre escolas e aulas do Recôncavo Baiano nesse período, também se tornaram fontes para pesquisas defendidas em Trabalhos de Conclusão de Curso da Licenciatura em História em 2017.

O LEHRB também atuou na produção de materiais didáticos, focando principal mas não exclusivamente a história regional. Tal direcionamento foi tomado depois de conversas com professores da rede pública, privada e com os discentes do curso, que identificaram a carência de representação da região em coleções e livros recebidos dos governos via PNLD e PNBE, levando o próprio professor a pesquisar conteúdo, coletar documentos e elaborar de apostilas com textos, imagens e vídeos.

A maneira mais rápida de intervir foi optar por materiais que não demandassem longo tempo para serem produzidos e disponibilizados. Entre dezembro de 2012 e dezembro de 2016 conseguimos uma bolsa de extensão para um estudante, dedicada à elaboração textos de divulgação histórica com temas regionais, cada um acompanhado de uma sequência didática. Como modelo para os textos de divulgação utilizamos os temas de aula destinados ao professor disponíveis no site da Carta na Escola / Carta Fundamental (da empresa Carta Capital). As sequencias tomaram como referência a produção orientada por Antonia Terra Calazans Fernandes, disponível no LEMADUSP. Tínhamos como objetivo disponibilizar, todo mês, um texto curto (5 laudas) acompanhado de sugestões de documentos e atividades, que era também uma forma de o graduando exercitar a síntese histórica, a escrita para o grande público e a mediação didática em História. Porém, o ritmo não foi o desejado, pois os bolsistas precisaram de um tempo maior que o esperado para se familiarizar com as atividades propostas e tinham dificuldades para localizar fontes e bibliografia sobre os temas que escolhiam. Quando atingiam um ponto ótimo, a bolsa era descontinuada e o processo reiniciava. No período de janeiro de 2013 a outubro de 2015 três diferentes bolsistas produziram seis 
textos de divulgação e seis sequencias didáticas, e dois textos ficaram pela metade sem ir para o site. Um último texto de divulgação, sobre práticas de cura no Egito Antigo, foi publicado em julho de 2017, redigido por um mestrando em tirocínio com base no tema de seu trabalho final.

Nesse mesmo ano, também subsidiados por bolsas institucionais e parcerias para tirocínio docente, publicou-se materiais didáticos mais complexos, de produção mais demorada, igualmente voltados à história local, como "Conceição da Feira: Roteiro Histórico" e "Redescobrindo Cachoeira: caderno de Estudos do Meio", e o livro infantil "O Cabelo que dava volta ao mundo", este acompanhado de um guia metodológico para a contação de Histórias.

Diante do exposto, seguimos as conclusões de JESUS e PERLI (2015, p. 230), para quem "a organização do Laboratório de Ensino de História moldou uma percepção de que o lugar é uma construção coletiva". No caso do LEHRB-UFRB, a percepção inicial, no curso de história e depois fora dele, era do laboratório apenas como espaço físico e virtual voltado ao suporte. Fruto da infraestrutura básica propiciada pela administração universitária e da doação de colegas, voltava-se ao empréstimo de livros, disponibilização da sala para reuniões e acesso virtual a links interessantes. Nos anos finais passou a ser percebido como um espaço de trabalho intelectual que se expressava em palestras, debates, oficinas e cursos. De usuários, professores universitários e da educação básica, graduandos e pós-graduandos (em curso ou egressos), estagiários bolsistas e servidores passaram a promover atividades, gerando um círculo de ampliação de colaboradores ocasionais.

Tal participação integrou três eixos: o interno, entre graduação, pós-graduação e docência universitária; o externo, o qual relacionou a universidade, as escolas da educação básica e a comunidade; e o virtual que, através da internet, conectava os demais eixos ao restante do mundo. Como efeito dessa integração e do incremento da infraestrutura e apoios, nos dois últimos anos o Laboratório pode contar com equipes de trabalho por períodos maiores de tempo, o que permitiu a implementação de ações de médio e longo prazo como projetos nas escolas e a elaboração de materiais didáticos mais complexos. O resultado dessas ações fez emergir uma terceira percepção do LEHRB, também visto como lugar propiciador de experimentos e pesquisas práticas.

A seguir detalharemos a vertente da produção de materiais didáticos do LEHRB, também sustentada por essa rede de colaboração voluntária que marcou outras atividades do Laboratório. Por questões de espaço, a análise da produção dos textos de 
divulgação ficará de fora. A ênfase será dada nos materiais cuja marca era ser produto de pesquisa aplicada na área de Ensino de História, nos níveis de graduação e pósgraduação.

\section{A produção de materiais didáticos no LEHRB}

Inicialmente, destacamos a produção oriunda da parceria com o Mestrado Profissional em História da África, da Diáspora e dos Povos indígenas. Em funcionamento desde 2014 no CAHL/UFRB, essa modalidade de pós-graduação strictu sensu permite trabalhos finais de curso em formatos distintos da tradicional dissertação, inclusive materiais didáticos. Dentre as disciplinas do curso, há uma voltada para a "Metodologia da Pesquisa e da Produção de Materiais Didáticos", um espaço de reflexão e exercício para essa finalidade (ALMEIDA, 2016; ALMEIDA, 2017). Ofertada no segundo semestre, sua dinâmica de leituras, paralelas às de outros componentes curriculares, bem como o pouco amadurecimento do projeto por vezes não são suficientes para apresentação de um protótipo do trabalho final.

Nesse sentido, pensamos que uma parceria com o LEHRB para realização de tirocínio obrigatório, componente curricular ofertado no segundo ou no terceiro semestre, pudesse avançar o trabalho iniciado no ano anterior. Ao invés de acompanhar um docente em uma disciplina da graduação, seria supervisionado pelo coordenador do Laboratório para realização de atividade relacionada à pesquisa de mestrado, como oferta de curso de extensão à comunidade, produção de textos de divulgação junto de sequência didática, ou de um material didático. Assim, sem se desviar dos objetivos ou dos prazos, e já tendo cursado as disciplinas, o mestrando teria uma experiência de ensino ou produção de materiais, enquanto o LEHRB aumentaria a oferta de materiais ou cursos gratuitos voltados aos professores e alunos do Recôncavo da Bahia. A formalização da parceria ocorreu em 2016 e os materiais foram publicados em 2017.

O primeiro foi Conceição da Feira: roteiro histórico. A motivação do autor Jadson Ferreira Santos surgiu de sua experiência profissional como docente em Conceição de Feira, município situado entre o Recôncavo Baiano e a região metropolitana de Feira de Santana. A ausência de materiais sobre História Local levou-o a conceber inicialmente um guia de leitura com saberes e biografias de moradores das comunidades e um material de apoio ao professor. Como estava envolvido em outro projeto acerca de educação patrimonial no município Cachoeira, as conversas iniciais com o supervisor, em setembro de 2016, levaram-no a aproveitar essa experiência e, 
daí, elaborar um produto para o LEHRB sobre Conceição da Feira que pudesse servir como etapa de seu trabalho final de curso, aproveitamento esse que não se efetivou posteriormente. Mesmo assim, Jadson passou a entrevistar alunos e depois moradores do município para elaborar um livro sobre o patrimônio material de Conceição da Feira que pudesse ser empregado na sala de aula.

Tal projeto continha três etapas, pesquisa nos arquivos e entrevistas, elaboração de um capítulo de paradidático, disponibilização para as escolas e realização de ações junto aos alunos. A exiguidade do tempo levou-o a limitar a pesquisa e eliminar a terceira etapa, deixada para outro momento. O material publicado no início de abril de 2017 consistiu em um pequeno catálogo de alguns lugares de memória de Conceição de Feira. Foi composto em três partes. Na introdução apresentava os objetivos, a localização geográfica (incluindo mapas) e um curto histórico do município até sua emancipação em 1926. A parte central intitulada "A História nos Lugares" consistia numa pequena descrição e histórico de seis lugares de memória, com pelo menos uma imagem ilustrando o texto. Por fim, as "Indicações" continham as referências bibliográficas e das imagens, os créditos e outras menções a sites ou livros sobre Conceição da Feira.

Além do exíguo tempo, a elaboração do livro esbarrou em duas principais dificuldades. A primeira esteve ligada à pesquisa das informações sobre os lugares de memória em Conceição da Feira. Na ausência de um arquivo municipal e do tempo hábil para realização e gravação de entrevistas, abriu-se mão de entremear as descrições com trechos das falas da população e de outros documentos, levando tanto à restrição das informações sobre os lugares quanto ao formato enciclopédico do texto. O mesmo ocorreu com as imagens, oriundas de fotografias pessoais ou extraídas de sites da internet e de um livro sobre o município. A outra dificuldade incidiu na apresentação do material final. Como não há, no LEHRB, profissional dedicado ao suporte gráfico e, nos cursos, tampouco formação que dê conta dos princípios básicos de diagramação ou capacitação no uso de ferramentas digitais, a parte gráfica dos materiais costuma ficar comprometida. Isso exigiu a intervenção do supervisor nessa etapa de preparação visual, acumulando mais essa função além da leitura crítica. Optou-se por não aproveitar toda a mancha com o texto, mas regular seu espaço para que cada lugar de memória descrito ocupasse uma ou duas páginas, sem quebras. O resultado pode ser visto abaixo: 
DOI: 10.47694/issn.2674-7758.v2.i6.2020.118148

Figuras 2 e 3: Capa e páginas do livro Conceição da Feira: Roteiro Histórico.
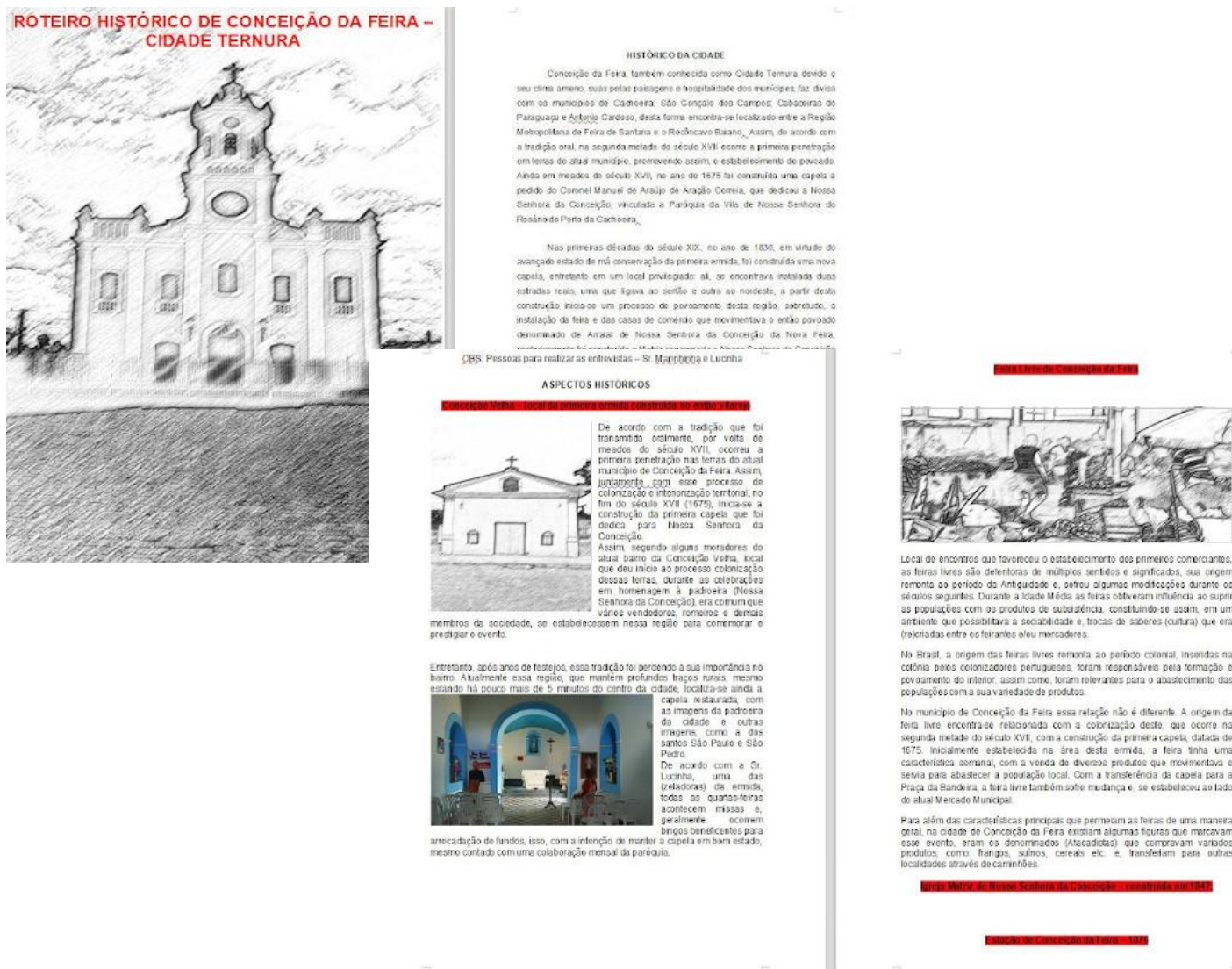

Fonte: Acervo

Figuras 4 e 5: Capa, Sumário e páginas do livro Conceição da Feira: Roteiro Histórico.
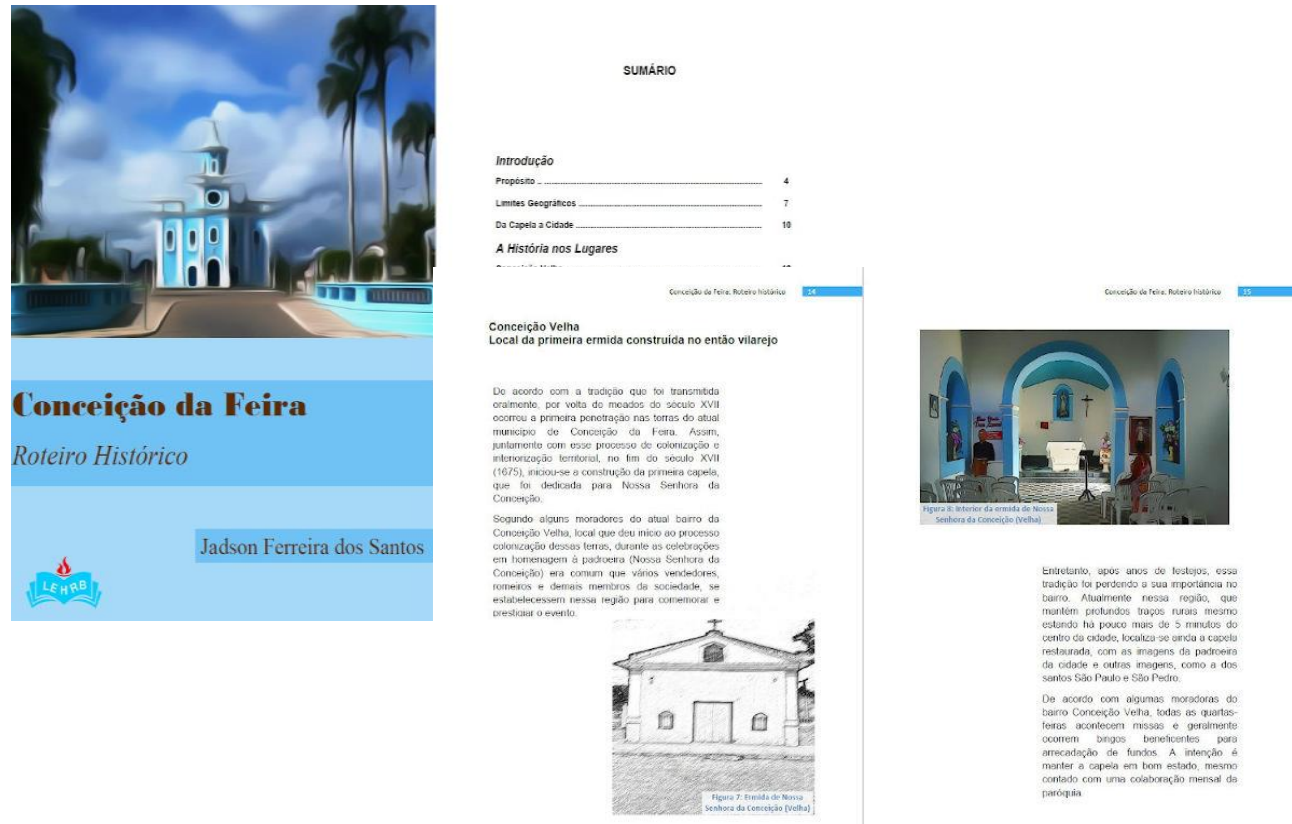

Fonte: Acervo 
O outro material fruto dessa parceria com o Mestrado Profissional teve outras condições. Começou antes mesmo do início do tirocínio, com a oferta de uma oficina de contação de histórias em abril de 2016 pelo mestrando Rogério Santos Souza, no âmbito do projeto Ilê de Memórias, abrigado pelo LEHRB. A intenção do mestrando era elaborar uma coleção de livros infantis com esses textos criados pelos participantes das oficinas e empregá-los como recurso didático na formação de alunos e professores da educação infantil no município de Maragogipe-BA, onde atua como docente, com o recorte da identidade étnico-racial em crianças, objeto do seu mestrado. Diante da amplitude do projeto, no início do tirocínio, em agosto de 2016, o supervisor recomendou a escolha de um único conto para que se tivesse um parâmetro do ritmo de produção e o formato da coleção.

A escolha de "O cabelo que dava volta ao mundo" foi feita após formação com professores e dirigentes de uma escola municipalizada de Maragogipe, para atender a necessidade de lidar com a discriminação que meninas negras sofriam em sala de aula. A história problematizaria tais atitudes ao narrar como a pequena Sol, menina negra de grandes cabelos crespos, ter que ir à escola com seus cabelos trançados e presos por obrigação da mãe. Um dia, ao ver um álbum de família adormece e sonha com Nanã, que tinha cabelos crespos e volumosos como os seus, e leva Sol a reconhecer sua beleza no espelho. Ao contar o sonho à mãe, esta reflete sobre suas atitudes e decide não mais prender o cabelo da menina. Na concepção do mestrando, "o conto, que passeia majestosamente no universo da ludicidade, permite importantes reflexões acerca do fortalecimento da autoestima, a partir da imagem positiva de crianças negras; indica, ainda, o quão importante é a representatividade e a inclusão de tais identidades" (SOUZA, 2017c, p. 68)

A produção do livro propriamente dito começou com uma oficina ministrada pelo mestrando na escola infantil, na qual narrou o conto e pediu para as crianças ilustrarem a estória. Devidamente autorizadas, essas ilustrações serviram de base para ilustrações profissionais, feitas por Daniela Barbosa, uma estudante do curso de Artes Visuais do CAHL/UFRB e bolsista do LEHRB. Além da crítica de Rogério, que apontou estereótipos visuais sobre a menina negra, as imagens elaboradas pela artista retornaram para os alunos em novos encontros na escola, para intervirem na composição. Por exemplo, as crianças chamavam atenção para o tamanho do cabelo de Sol e de sua avó, a presença dos óculos etc. Ao atingir um ponto satisfatório para todos, as imagens foram coloridas, digitalizadas e encaminhadas para Julius Sá, profissional 
contratado pelo mestrando para dar conta do projeto gráfico e da diagramação do livro. O protótipo passou por outras leituras críticas, tanto do supervisor do tirocínio quanto das próprias crianças, e com os ajustes chegou-se à versão final.

Paralelamente, o mestrando elaborou um material de apoio voltado aos professores da educação infantil, cujos dez capítulos abordavam temas variados: a experiência do mestrando nesse nível de ensino, histórico da educação infantil no mundo e no Brasil, problemática e as leis sobre educação étnico-racial, aspectos metodológicos sobre a contação de histórias, apresentação do conto "O cabelo que dava volta ao mundo", sugestões de trabalho e de leitura. O mestrando contratou outro profissional, Romielle Evangelista, para seu projeto gráfico, no qual se aproveitou algumas das ilustrações que não serviram de base para o livro infantil. Em julho de 2017, ambos os materiais foram disponibilizados para o público no site do LEHRB.

Figuras 6 a 9: Versões da personagem Nanã de O Cabelo que dava volta ao mundo. As duas da esquerda foram as ilustrações das crianças. A terceira é a versão original da ilustradora, com cabelos curtos e sem óculos. A discrepância apontada pelas crianças levou à reinserção dos óculos e aumento do cabelo na versão final, da direita.

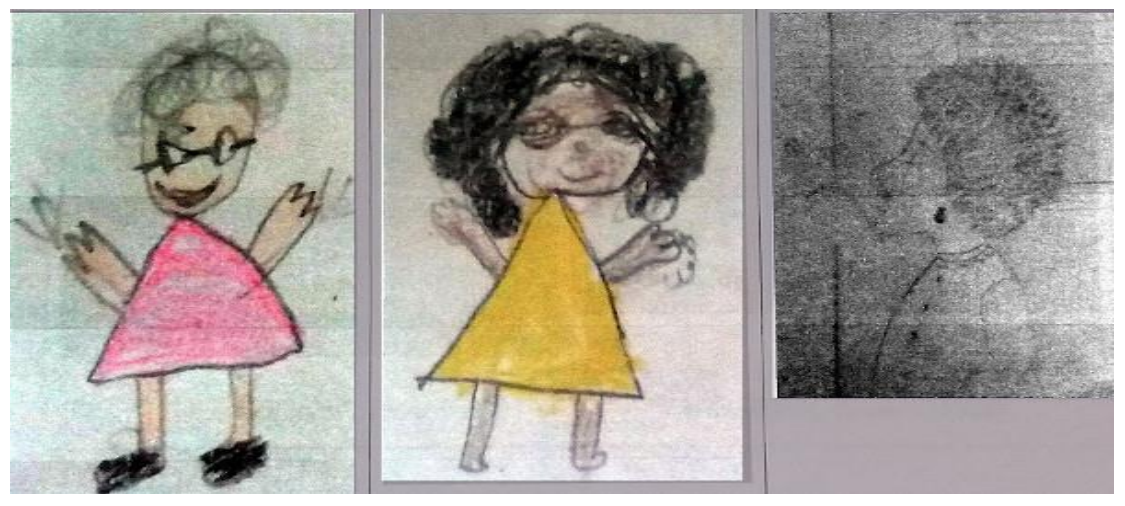

Fonte: (SANTOS, 2017c, p. 77)

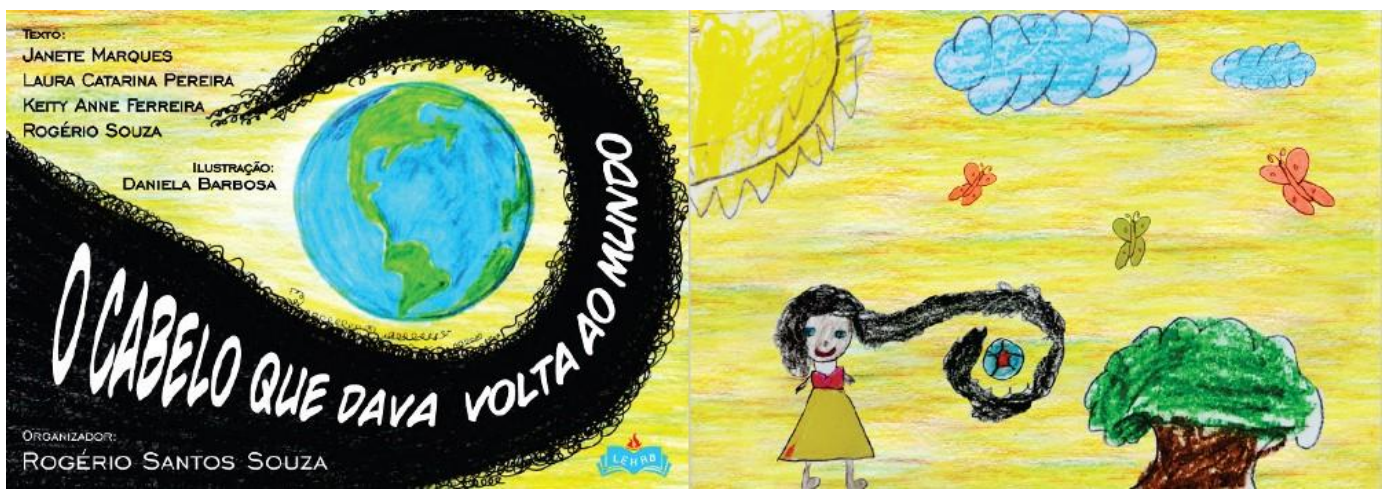


Figuras 10 e 11: Capa, folha de rosto e páginas do livro infantil $O$ Cabelo que dava volta ao mundo

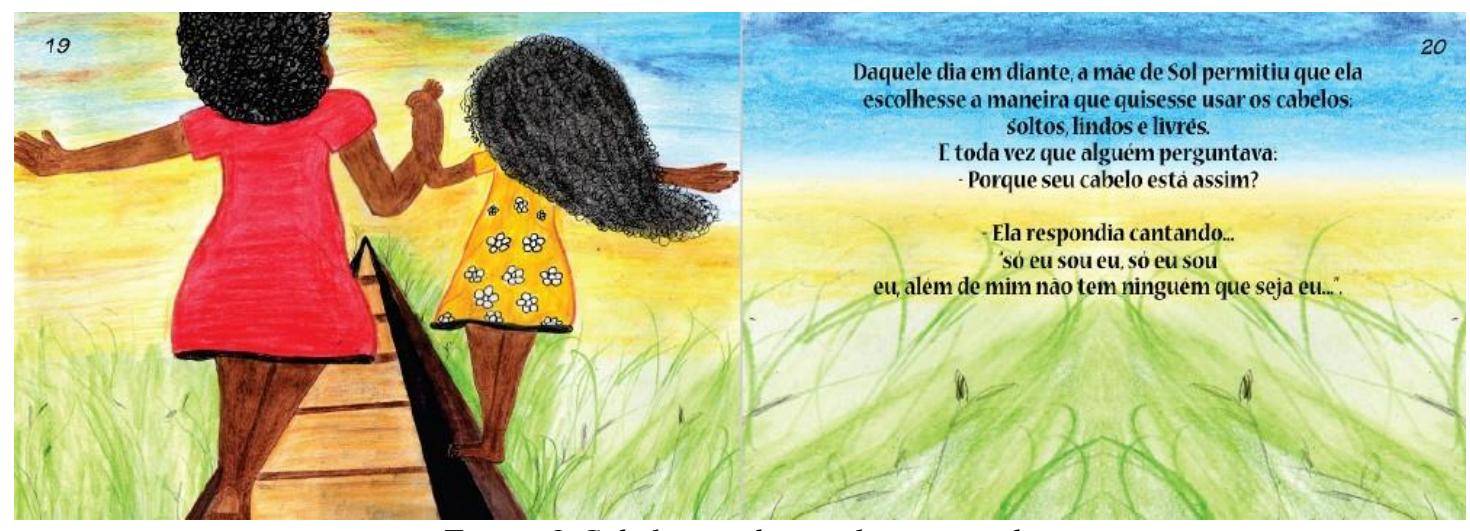

Fonte: $O$ Cabelo que dava volta ao mundo

Figuras 12 a 14: Capa, abertura de capítulo e páginas do livro para o professor
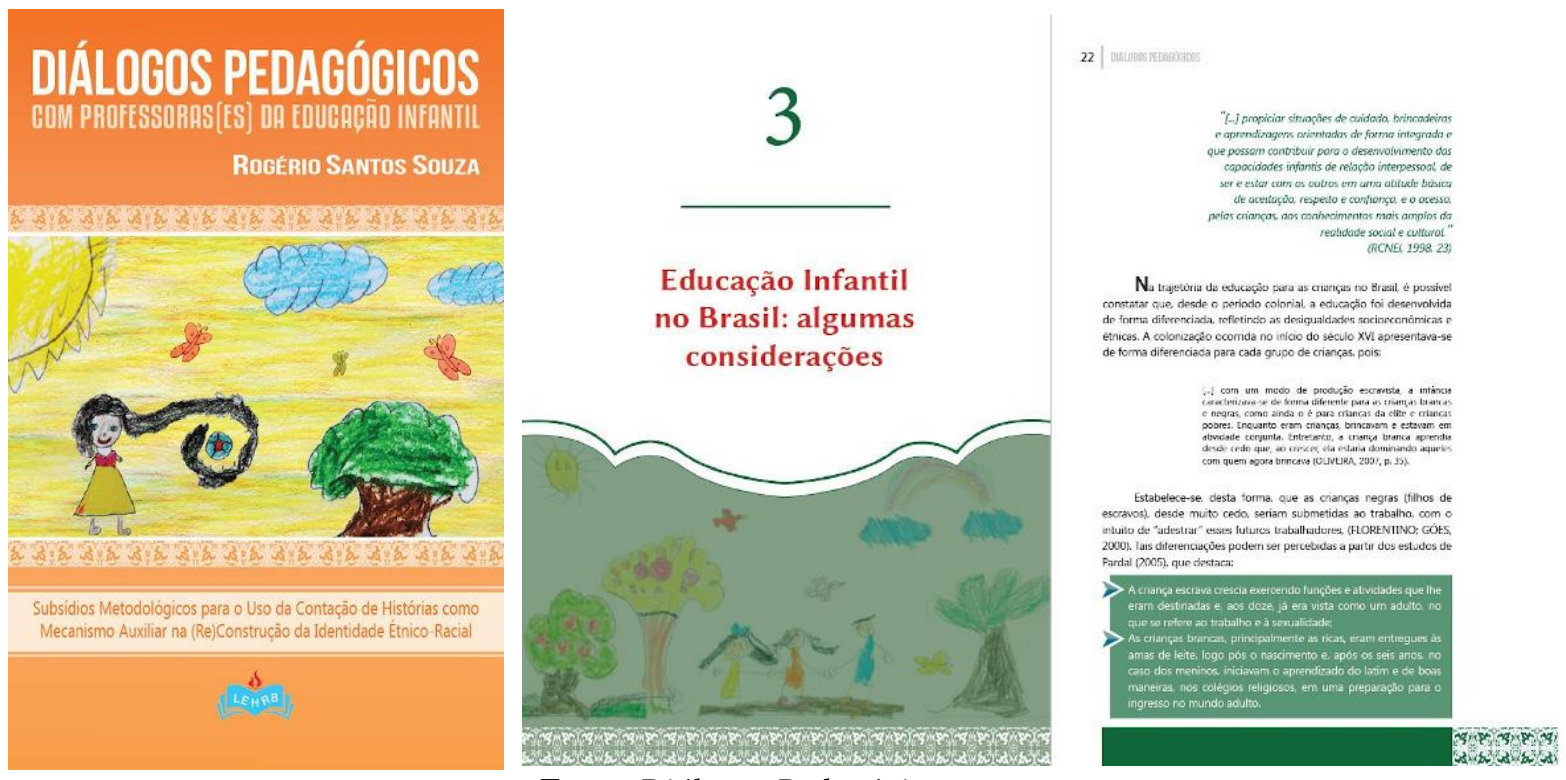

Fonte: Diálogos Pedagógicos

Os materiais produzidos no âmbito do projeto "Ilê de Memórias" são fruto de uma conjunção entre o LEHRB, o mestrado profissional e a comunidade escolar, aí inclusas as crianças de três a cinco anos. O tempo maior de trabalho do mestrando, superior a um ano, o auxílio de uma bolsista da área de artes e a supervisão da coordenação permitiram a elaboração de um livro infantil e outro ao docente cujo conteúdo conseguiu dar conta das preocupações com a educação étnico-racial para esse nível de ensino. A principal dificuldade residiu, novamente, na parte gráfica e diagramação, sobretudo do livro de poio, solucionada com a contratação, pelo próprio mestrando, de profissionais externos para esse trabalho. Essa finalização colocou os produtos em outro patamar, nada a dever aos equivalentes do mercado editorial. Tanto 
que, após o término do tirocínio, o material foi submetido e aprovado na qualificação e na defesa de mestrado sem modificações estruturais. Logo, foi cumprido o objetivo de tornar o estágio do mestrando no LEHRB em uma etapa de elaboração didática e da submissão do produto a sucessivos e diferenciados olhares críticos, fundamentais para sua reformulação e melhoria.

Diferente dos anteriores, o último material foi fruto de um projeto do próprio LEHRB que surgiu a partir de um estágio não-obrigatório da graduação, com uma bolsa da Pró-Reitoria de Pessoal concedida a Sulamita Pinto Lima. Em fins de 2014, após reuniões, acordamos que parte da carga horária seria dedicada à elaboração de um caderno de estudos do meio sobre a cidade de Cachoeira. Ao tomar conhecimento do projeto o estudante Sandro Augusto da Silva Cerqueira Júnior integrou-se voluntariamente à equipe. Nesta condição a própria Sulamita permaneceu após o corte de sua bolsa, em agosto de 2015, até o encerramento do projeto em abril de 2017. O longo período foi interrompido tanto pelas atividades dos discentes, que participaram de outros projetos como o PIBID, terminaram a graduação em história e adentraram no mestrado, como aquelas pausas da própria universidade como greves, férias e recessos. Em novembro de 2016 a equipe foi também integrada pelo artista plástico voluntário Romielle Evangelista, responsável pelo projeto gráfico, diagramação e paginação.

O ponto de partida foi um material já existente, o Caderno de Estudos do Meio "Caminhos da Liberdade", coordenado por Antonia Terra Calazans Fernandes, sobre o bairro da Liberdade, em São Paulo, e produzido em 2013 em uma oficina da ANPUHSP e publicado no site do LEMAD-USP. Um caderno dessa natureza tem a finalidade de auxiliar as atividades pedagógicas realizadas extramuros, em uma imersão voltada à observação direta da cidade ou do bairro, método atualmente denominado Estudos do Meio (LOPES, 2014, p. 24-28). Daí porque tal recurso auxiliar pode trazer roteiros e mapas, informações, espaço para registro pessoal e fontes diversas que permitem deslocar ou problematizar a percepção daquilo que está sendo visto. O caderno elaborado pela equipe do LEMAD tem essas características, contendo inúmeras fotografias antigas e novas, mapas e imagens de satélite do bairro da liberdade, espaços para registros, textos de diversos gêneros como decretos e notícias de jornais. Então, a primeira recomendação aos historiadores da equipe do LEHRB foi um estudo da bibliografia sobre Estudo do Meio, começando pela dissertação de Danilo Eiji Lopes (2014), e uma leitura atenta do material coordenado por Antonia Terra para familiarização com o modelo. A partir daí pensamos uma adaptação de um caderno para 
Cachoeira-BA, uma cidade quadricentenária tombada pelo IPHAN, com rico patrimônio material, natural e imaterial, ligado ao período colonial e imperial, e à cultura afrobrasileira:

Figura 15: Página do Caderno de Estudos do Meio "Caminhos da Liberdade"

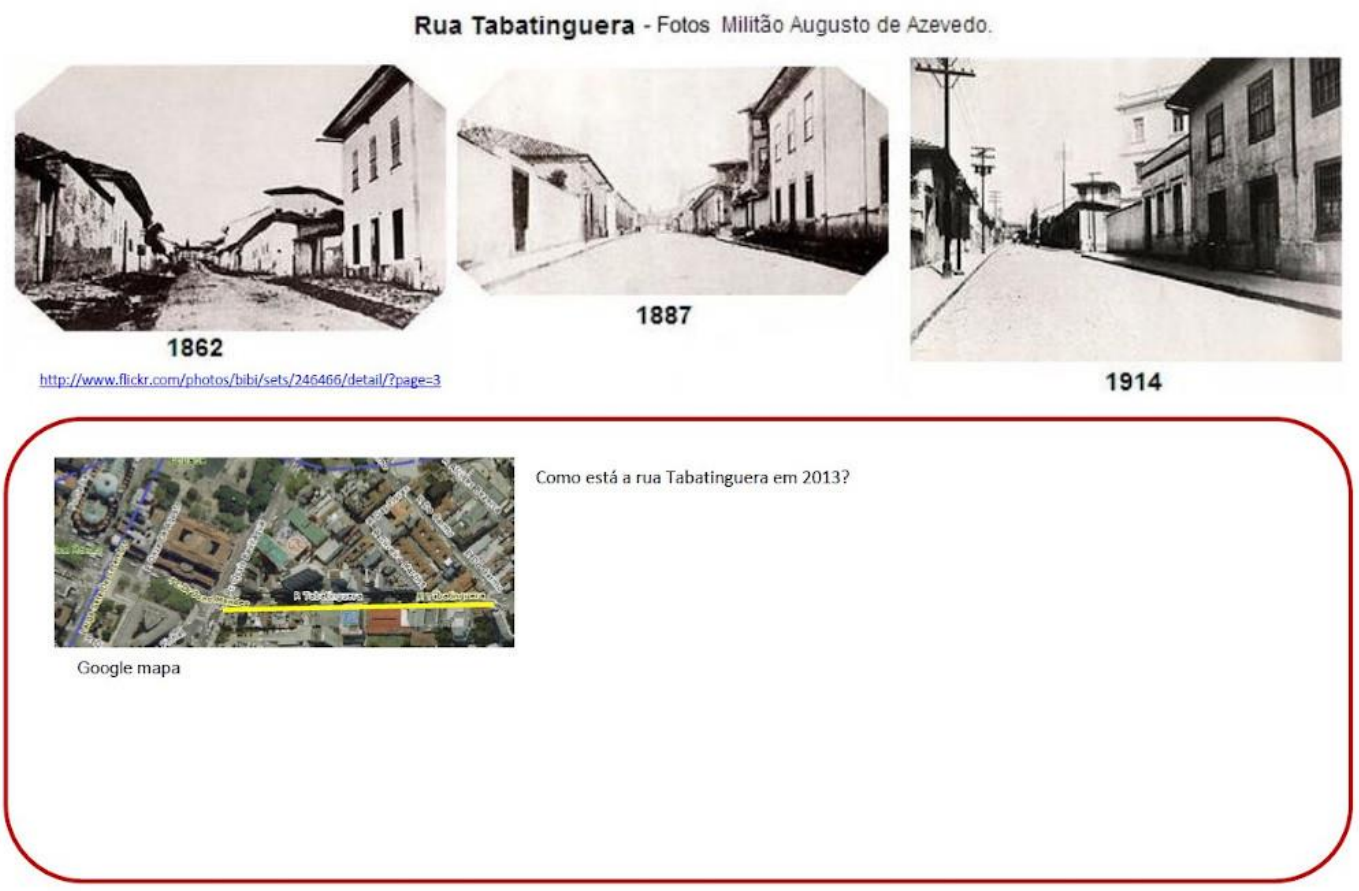

Fonte: (FERNANDES et alii, 2013, p. 14)

O Caderno de Estudos do Meio produzido no LEHRB tem semelhanças com aquele do LEMAD, com capa, um mapa do roteiro no início, imagens com legendas, documentos e textos informativos, linhas para registro de impressões do leitor e box para desenhos. Mas, ao longo da elaboração do material, o modelo sofreu modificações. A principal delas ocorreu após a fase da pesquisa de imagens e informações. Em vez de um roteiro contínuo, os estudantes escolheram dividir o caderno por blocos, recortando por temas com os quais estavam familiarizados e sobre os quais possuíam mais fontes e bibliografia por conta da elaboração do TCC ou da participação em outros projetos de pesquisa. Deixar de lado lugares famosos do município possibilitou a emergência de outros menos visíveis e mais presentes no cotidiano. Outras modificações também ocorreram, como a inserção de roteiros de entrevista para capturar a memória de outras pessoas sobre o elemento observado, ilustrações que não serviam como documento, uma apresentação ao estudante e um sumário, páginas divisórias entre os temas, e um espaço para avaliação e créditos do material. Além disso, na execução, notamos um 
menor uso de mapas e fontes escritas. Assim, o material final produzido pelo LEHRB continha uma introdução com apresentação e o roteiro de dez lugares, os quatro blocos temáticos (transportes e desenvolvimento, religiosidade e resistência, economia e sociedade - feira livre, enchentes), encerrando com uma página com imagens de outros lugares da cidade, outra de avaliação, finalizando com créditos e ficha técnica.

A elaboração do material contou com uma pesquisa feita na internet, em arquivos da região, livros, e conversas com estudiosos locais, os quais contribuíram com material e informações extras sobre os lugares. Também aproveitou a experiência prévia que os dois autores tiveram, um Estudo do Meio por Cachoeira realizada em dezembro de 2014 com turmas do Ensino Fundamental II do Colégio Estadual Edvaldo Brandrão, de Cachoeira, e do Ensino Médio Técnico do IFBaiano de Catu. Esta sessão permitiu reunir percepções e impressões de alunos de dentro e de fora do município que formataram as indicações de visualização das imagens e leitura dos textos. Além disso, a intervenção de um artista plástico nas etapas finais modificou qualitativamente o projeto gráfico, dando-lhe feições editorialmente profissionais em relação às versões iniciais. Por fim, a leitura crítica dos protótipos feita pela supervisão escoimou falhas na disposição das imagens, apontou ausência de legendas informativas, disposição dos textos para que dialogassem entre si, e erros nos textos. A evolução gráfica do produto pode ser visualizada abaixo: 
Figuras 16 a 19: Páginas do Caderno de Estudos do Meio do LEHRB
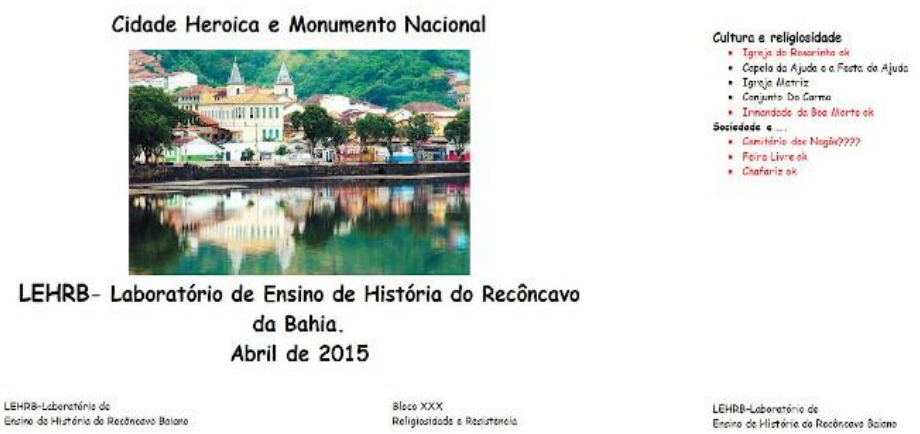

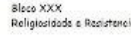

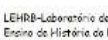
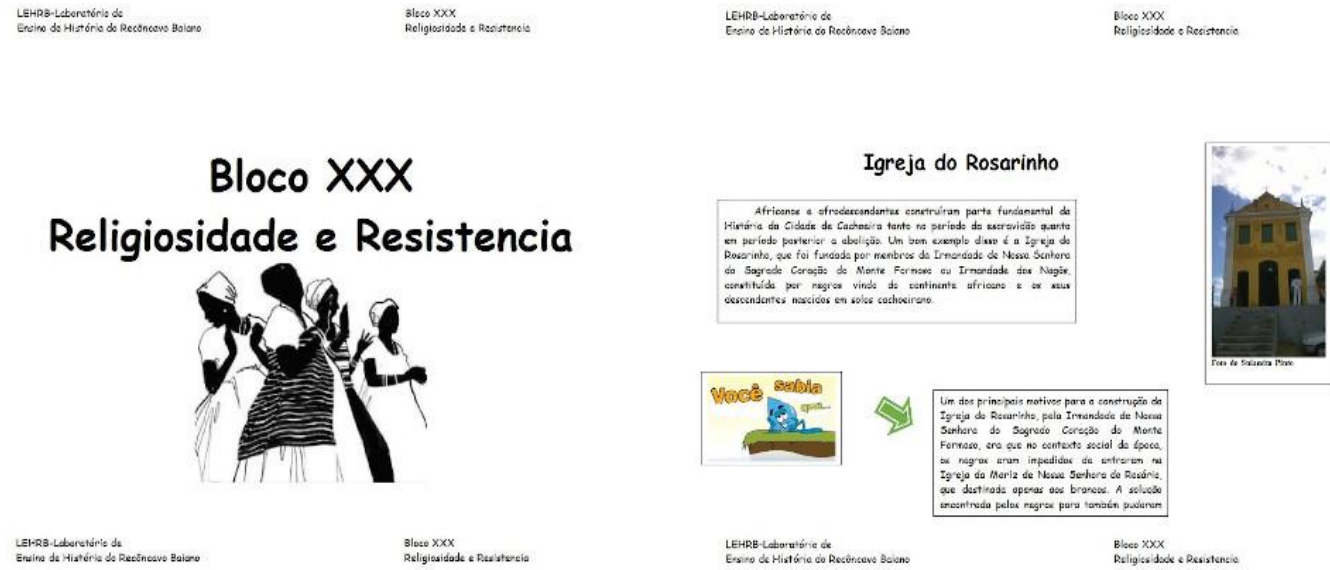

Fonte: versão dos autores Sulamita e Sandro, de jun./2015.

Figuras 20 a 23: Páginas do Caderno do LEHRB

Cidade Heroica e Monumento Nacional

LEHRB - Laboratório de Ensino de História do Recôncavo da Bahia. Abril de 2015

Estudo do Meio - Cachoeira

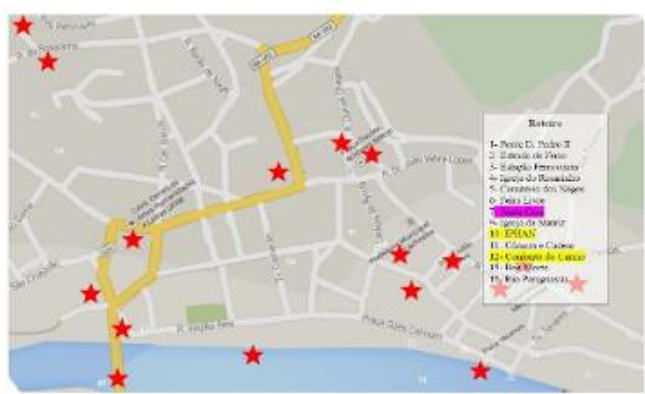

\section{Bloco II}

Religiosidade e Resistencia
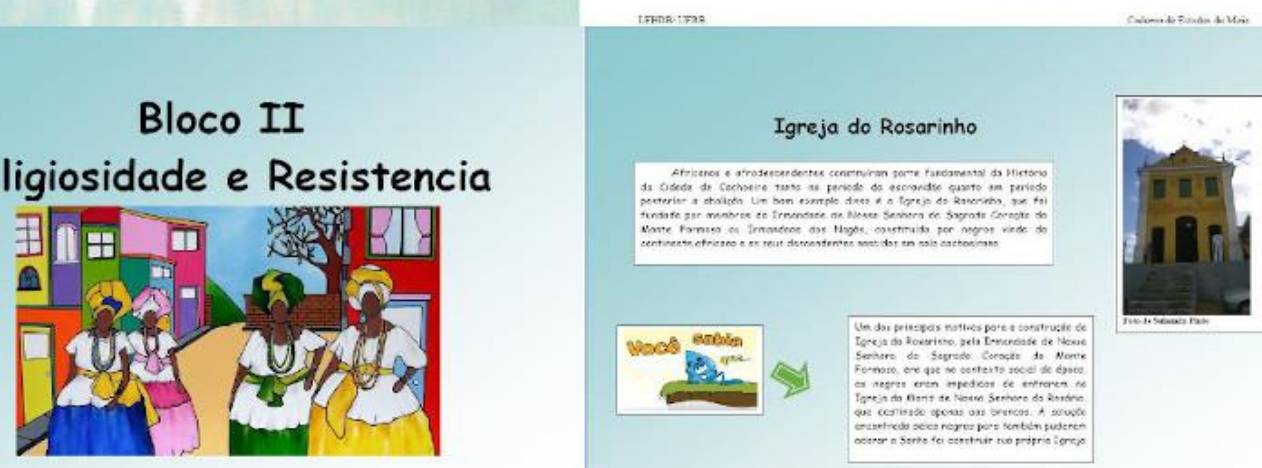

Fonte: Versão de outubro de 2016, após intervenções no projeto gráfico 
Figuras 24 a 27: Páginas do Caderno de Estudos do Meio "Redescobrindo Cachoeira"

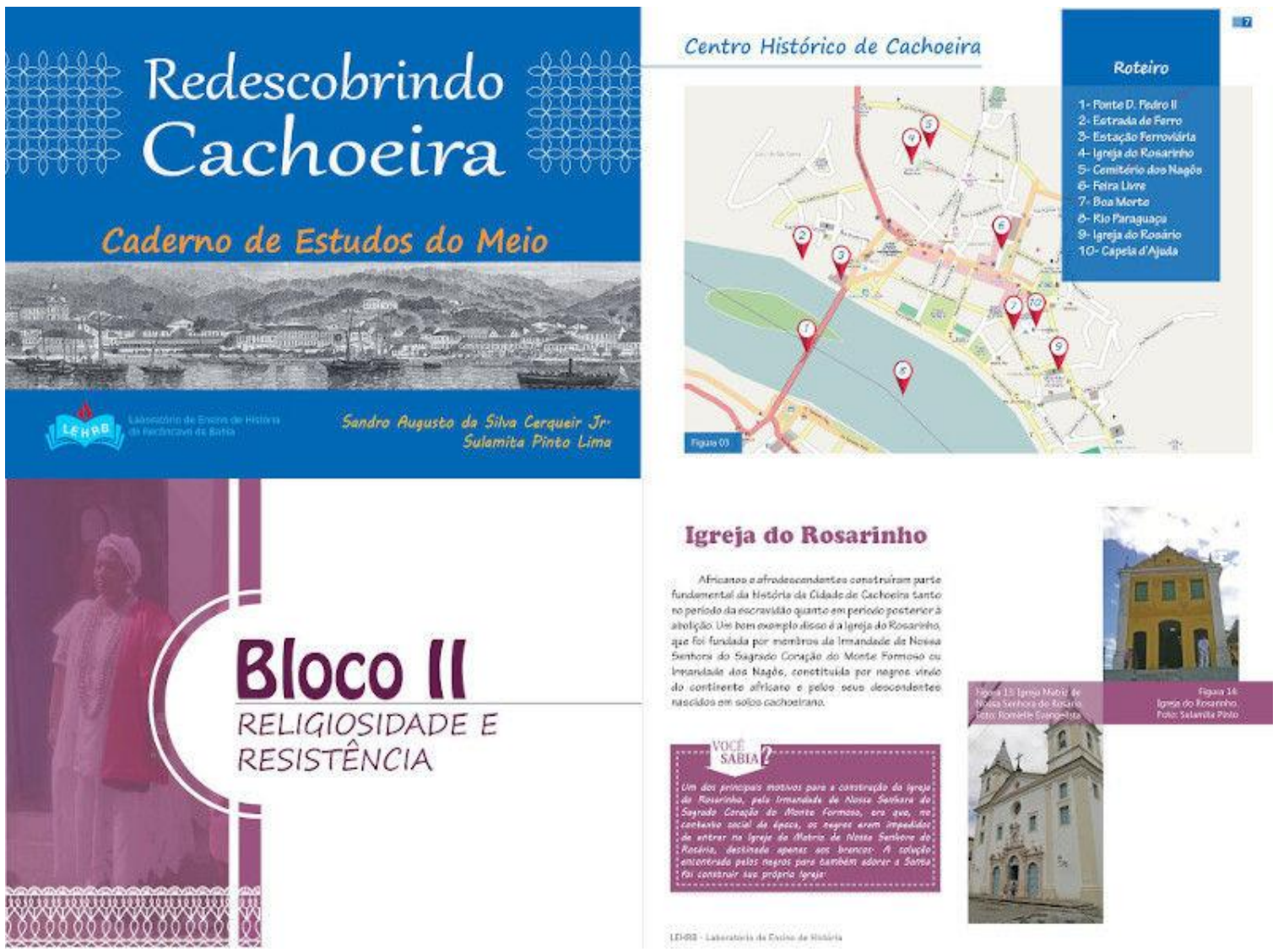

Fonte: versão final de abril de 2017, com intervenções gráficas do artista plástico Romielle Evangelista

\section{Balanço das três experiências}

Os materiais didáticos foram concebidos por nós no sentido de "suportes informativos", que "correspondem a todo discurso com intenção de comunicar elementos do saber das disciplinas escolares", os quais podem integrar em seu interior aquela outra categoria que Circe Bittencourt (2008, p. 296) denominou documentos. Devido a essa intenção, é possível generalizar para os demais suportes as características complexas dos livros e coleções didáticas de História, já que veiculam conhecimentos históricos escolares, em conexão com os saberes teóricos, conceituais e temáticos da historiografia; conhecimentos pedagógicos, ao propor mecanismos de aprendizagem; valores e ideologias; e, por fim, são um produto "fabricado por técnicos que determinam seus aspectos materiais" (BITTENCOURT, 2008, p. 301-302). Cabe então perguntar como, no LEHRB, graduandos e pós-graduandos docentes lidaram com a elaboração de materiais didáticos, como se articulam os saberes das disciplinas de referência, saberes pedagógicos, os saberes de manipulação das linguagens (visual e escrita) e os saberes da prática ou da experiência. Logo, em analogia com a aula (MONTEIRO, 2007, cap. 3; 
TARDIFF, 1992, cap. 1), indagamos como os docentes lidam com múltiplas dimensões e complexidades da produção didática?

É possível generalizar para os outros trabalhos a percepção de Rogério Souza ao caracterizar os processos de elaboração dos materiais como "extremamente prazerosos, apesar de exaustivos". No seu relatório, a dimensão prazerosa deriva sobretudo da concretização de um produto que atenda uma necessidade educacional e social, a “preocupação em não produzir um material pedagógico que permanecesse reproduzindo um imaginário em que as populações negras são, quase sempre, retratadas de forma preconceituosa, pejorativa e estereotipada" (SOUZA, 2017c, p. 81-82). Essa mesma preocupação antirracista aparece ligada à recuperação e valorização de uma história local, sob a perspectiva do patrimônio, nos outros dois materiais produzidos. Jadson Santos afirma que "ao analisarmos os livros didáticos de História utilizados pela escola na qual era professor, verifica-se o quanto estes não favoreciam o reconhecimento dos alunos/as negros/as com relação à sua participação nos processos históricos, não maximizam os estudos sobre o patrimônio (material e imaterial) local, nem tampouco fomentam a construção identitária dos discentes e docentes” (SANTOS, 2017, p. 5). Tais falas emergem da percepção de carências da realidade e de insuficiências nos materiais existentes, como a ausência da história local ou perspectivas pouco favoráveis à discussão racial. Visando superar aspectos vistos como limitadoras da prática docente, as expectativas engajadas são uma dimensão fundante, orientando escolhas e reformulações.

No caso dos professores mestrandos, tal experiência docente foi determinante, já que a produção de ilustrações ou narrativas (Rogério) ou a coleta de informações sobre o município (Jadson) derivam da interação com a comunidade escolar da localidade visada. À experiência docente, se integrou saberes acadêmicos adquiridos na graduação e no mestrado, sobretudo aqueles referentes às questões raciais e de história local/patrimônio, que se somaram a experiências profissionais não-escolares, como o trabalho com Patrimônio por Jadson ou a prática de contação de histórias por Rogério. No caso dos estagiários de graduação como Sandro e Sulamita, as escolhas do encaminhamento do Caderno estão ligadas aos saberes acadêmicos, derivando das pesquisas realizadas para o Trabalho de Conclusão de Curso (TCC), que se somaram à vivência pedagógica com estudantes do ensino Fundamental e Médio, adquirida em programas de extensão como PIBID. Com pontos de partida distintos, durante a produção do material a tendência foi a integração de saberes de diferentes naturezas, 
acadêmicos, pedagógicos e experienciais, embora apenas os dois primeiros estejam visíveis.

À luz de trabalhos anteriores (ALMEIDA, 2016 e 2017), já esperávamos que o caráter "exaustivo", a maior dificuldade para os estudantes, viria do trato com dimensões distantes da formação do historiador, em especial a diagramação e projeto gráfico. Nesse momento foi preciso refletir e implementar soluções ligadas à visualidade e apresentação, não apenas sobre o conteúdo histórico ou propostas pedagógicas. Embora menos presente no processo de elaboração de Conceição de Feira, nos materiais Redescobrindo Cachoeira e, principalmente, em $O$ Cabelo que dava a volta ao Mundo a percepção da relevância da diagramação e das regras próprias da visualidade foi mais profunda pelo contato maior com profissionais. Além de lidar com novos saberes, foi preciso raciocinar e deliberar sobre divergências e reformulações entre o almejado pelo historiador e o executado pelo artista gráfico. No livro infantil essas questões apareceram com mais intensidade porque a opinião das crianças foi determinante para a elaboração das ilustrações, reorientando as perspectivas do historiador-professor e da ilustradora. Daí a importância de outros atores, indiretamente envolvidos na fase de testes dos protótipos, que podem oferecer críticas e novas perspectivas ainda durante a elaboração do material. Logo, reforçamos o fato que quanto mais coletivo e interdisciplinar for o processo, mais rica a formação e melhor o produto.

Cada projeto facultou aos graduandos e mestrandos a vivência prática, sob uma nova perspectiva, da distinção que permeia os estudos acadêmicos no campo do Ensino de História, entre o saber acadêmico e o escolar, e as operações de didatização que separam o segundo do primeiro (BITTENCOURT, 2005, cap. 1; MONTEIRO, 2007, p. 83-93; NÓVOA, 2011). Mesmo em um projeto com foco apenas na dimensão informativa, como Conceição da Feira: roteiro histórico, houve menos a simplificação de informações enciclopédicas do que a construção de um conhecimento novo, apresentado para um público local escolar por meio de textos e imagens ilustrativas. No caso de Redescobrindo Cachoeira, além das informações sobre a história local, os estagiários mobilizaram textos e imagens como documentos, ressaltando aí aspectos do trabalho do historiador, e interagiram com o leitor escolar através de questões e atividades para trabalhar a relação passado-presente por meio da paisagem da cidade. Mesmo com o auxílio de um diagramador, o desafio foi configurar em uma página ou em páginas contíguas os documentos pesquisados, para estabelecer relações históricas 
DOI: 10.47694/issn.2674-7758.v2.i6.2020.118148

entre imagens que fossem pedagogicamente coerentes e, ao mesmo tempo, suficientemente abertas para permitir intervenções do professor segundo seus próprios objetivos. Portanto, foi preciso considerar o conhecimento histórico à luz dos diversos sujeitos da relação pedagógica sem prescindir das finalidades didáticas dos elaboradores.

Pelas especificidades ligadas ao ensino infantil, no projeto Ilê de Memórias essa problemática aumentava, tanto que ensejou dois materiais, um para instrumentalizar o professor com a metodologia de contação de Histórias, e outro para a educação étnicoracial das crianças. Este pressupunha a fruição direta de imagens e a mediação textual pela oralidade, com entonação e teatralização, que valorizavam a identidade negra em uma narrativa sobre os cabelos da protagonista. O docente mestrando levou em conta a especificidade do público pré-escolar ao ponto de incorporar as perspectivas e desenhos das crianças no material, sem perder de vista o objetivo de trabalhar o preconceito. Já no diálogo com os docentes esperava-se eliminar hierarquizações com um texto que abrisse possibilidades de múltiplos usos da história, permitisse reflexões sobre a metodologia e sobre a educação étnico-racial para crianças.

Além disso, no enredo de $O$ Cabelo que dava volta ao mundo aparecem a noção de fonte histórica (no álbum de fotografias), de memória e narrativa (o relato da mãe sobre a avó), e noções de diferença temporal e ancestralidade (entre a avó falecida, a mãe e a própria criança). Tais elementos permitem a docentes e pesquisadores trabalhar e analisar o desenvolvimento do conhecimento histórico em crianças de 3 a 5 anos, um desafio para o campo de pesquisa em Ensino de História, já que a educação infantil se tornou etapa da educação básica em 2009 e foi incluída na Base Nacional Curricular Comum (BNCC).

Após encerrar a elaboração, os materiais foram submetidos à comunidade, disponibilizados gratuitamente no site. Seus autores foram convidados a socializar a experiência em um evento promovido pelo Laboratório, "Produção de Materiais Didáticos no LEHRB: caminhos interdisciplinares na pesquisa aplicada em História”, ocorrido em 23 de maio de 2017. Professores da educação básica, estudantes de graduação e pós-graduação questionaram os caminhos e justificativas das escolhas. Continuando um processo já iniciado com a leitura crítica feita pelo supervisor, a partir das percepções dos colegas de profissão os autores revisitaram suas próprias motivações, os sentidos atribuídos ao material, bem como os limites intelectuais, pedagógicos e até financeiros da empreitada. Logo, o processo de formação docente não 
terminou com a finalização do produto didático. Houve cobranças ligadas à ausência de temas não abordados, considerados relevantes para os ouvintes, ou então à indisponibilidade de edições impressas, mais fácil de serem manuseadas pelos alunos das escolas públicas, os quais nem sempre tem acesso a computadores, celulares ou tablets.

Já os elogios permitiram avaliar o alcance dos resultados esperados, a exemplo do comentário da professora "Maria Malaquias", feito na postagem do livro de Rogério no site:

Prezado Prof. Rogério, muito obrigada pela produção! Achei o livro muito bonito, cuidadosamente construído para positivar a imagem de crianças (meninas) negras. Temos carência de produtos com essa qualidade no mercado literário e especialmente nas escolas públicas brasileiras, onde a maioria das crianças da educação infantil são negras. Quero falar sobre o material do professor. Eu sempre tive muita resistência em utilizar o "manual" do professor e achei que sua produção seria mais um desses materiais que tentam nos dizer o que fazer em nossas salas de aula. Tão grata surpresa de perceber que seu material não é um desses "manuais". Além de uma escrita muito boa (você parece estar conversando mesmo com a gente) você apresenta suas experiências (composta por tentativas, ações positivas e não tão positivas) o que nos faz perceber que é importante experimentar diversas práticas pedagógicas para encontrarmos uma forma que melhor atenda às necessidades das crianças que trabalhamos. Os passos que você indica para utilizarmos ao contar uma história além de muito objetivo é extremamente eficaz. Li sua produção numa manhã e hoje à tarde contei uma história para meus alunos e o resultado foi surpreendente. A importância de conhecer a história, montar as características dos personagens previamente, a posição que o livro deve ficar, o tom da voz, o olhar para as crianças... todos os passos são, de fato, muito preciosos. Obrigada por preocupar-se pelo ensino infantil, etapa que ainda é muito marginalizada na estrutura educacional brasileira. Obrigada por entender, respeitar e dialogar com cuidado e atenção com seus pares (nós professoras de crianças pequenas)! (Site do LEHRB, O Cabelo que dava volta ao mundo, 5/7/2017)

A mensagem da professora utiliza o livro como motivo para refletir sobre a educação. Trata da marginalização da etapa infantil, da necessidade de suas alunas negras, do contato frustrado com outros manuais do mesmo tipo, da elogiada apresentação gráfica, da linguagem e utilidade do livro para o professor, que propiciou uma reconfiguração da ação pedagógica no sentido por ela desejado. Maria avalia o sistema educacional, metodologias de ensino e produção de livros didáticos orientada pela experiência e direcionada para a atuação em sala de aula. Não por acaso ressalta o fato de Rogério ser um colega que se coloca a partir de suas experiências (bem e malsucedidas) e trata a leitora como igual. 
O comentário de Maria vai ao encontro das reflexões de Antonio Nóvoa (2011), quando o pesquisador português crítica a profusão e pobreza de discursos e saberes especializados que subalternizam, desvalorizam e visam controlar a ação dos professores, bem como seu chamado para renovação das complexas práticas docentes a partir de referências internas e concretas ao trabalho elaborado, reelaborado e refletido por uma coletividade de aprendizado profissional. Foi o que ocorreu com os três materiais do LEHRB. Embora mediada teórica e tecnicamente por saberes situados em um laboratório de ensino de História e em outros espaços/cursos na UFRB, o processo de produção didática foi conduzido pelos próprios profissionais da educação básica, a partir de suas experiências e necessidades, voltou-se para atender seus objetivos, cujos resultados foram compartilhados com os colegas em uma publicação gratuita. O comentário acima evidencia como a mediação do LEHRB conectou duas práticas, as que originaram a elaboração do livro pelo autor e a que emergiu da apropriação do livro pronto no site.

\section{Finalizando...}

Espaço de suporte, lugar de trabalho, lugar de experimentos, portanto espaço de formação. Acreditamos que a produção didática feita no LEHRB-UFRB conseguiu realizar os três sentidos para atingir os objetivos do Laboratório na área de Ensino de História. Para isso algumas condições tiveram que ser atendidas. Primeiro, a paulatina implementação de uma infraestrutura, não apenas composta de um espaço, equipamentos e acervos, como do direcionamento de recursos públicos da universidade na forma de alocação de funcionários e bolsas para graduandos, que garantiram o suporte a diversas ações. A outra foi a constituição de uma rede de colaboração, que ia da doação de materiais ao trabalho voluntário, pontual ou continuo, de profissionais e estudantes, sem os quais o Laboratório como espaço intelectual, na forma de eventos e projetos, não existiria. Atendidas minimamente tais condições, foi importante estar alerta para não tomar os professores e graduandos como deficitários e depositários de saberes, e sim concebê-los como sujeitos, como produtores.

Daí porque a condução da elaboração didática esteve a cargo dos professores e graduandos, os quais, segundo suas necessidades, deram o sentido e o tom do trabalho. Por isso foram considerados os autores dos materiais. Isso não apenas lhes permitiu se assenhorar do processo pedagógico como tomar consciência da complexidade, das escolhas e condicionamentos que envolvem a produção de materiais didáticos, limitados 
pelas possibilidades técnicas e pelos saberes dos outros integrantes da equipe. Por sinal, tais saberes foram exercitados durante a elaboração, já que os historiadores tiveram que mobilizar sua experiência e conhecimentos pedagógicos e acadêmicos, bem como confrontá-los com aqueles de outras áreas como informática e artes visuais. Desse trabalho e confronto resultaram materiais didáticos que puderam ser apropriados por outros docentes da educação básica no Recôncavo. Além do produto final, são importantes a prática e a percepção oriundas do processo ocorrido no LEHRB, pois permitem que a produção didática possa ser feita também na escola, necessariamente composta por profissionais de diversas disciplinas e, quem sabe, pode contar com auxílio ou até o protagonismo dos próprios alunos.

\section{Referências}

\section{Materiais Didáticos}

LIMA, Sulamita Pinto e CERQUEIRA JÚNIOR, Sandro Augusto da Silva. Redescobrindo Cachoeira: caderno de estudos do meio. Cachoeira, BA: LEHRB, 2017. Disponível em https://www3.ufrb.edu.br/lehrb/2017/04/18/caderno-estudos-meiocachoeira/.

SANTOS, Jadson Ferreira. Conceição da Feira: roteiro histórico. Cachoeira, BA: LEHRB, 2017. Disponível em https://www3.ufrb.edu.br/lehrb/2017/04/03/conceicaode-feira-roteiro-historico/.

O Cabelo que dava volta ao mundo. Cachoeira, BA: LEHRB, 2017a. Disponível em https://www3.ufrb.edu.br/lehrb/2017/07/04/cabelo-volta-mundo/.

SOUZA, Rogério Santos. Diálogos Pedagógicos com professores da educação infantil. Cachoeira, BA: 2017b. Disponível em https://www3.ufrb.edu.br/lehrb/2017/07/04/cabelo-volta-mundo/.

TERRA, Antonia et al. Caminho da Liberdade (ou da forca - territórios invisíveis). São Paulo: LEMAD-USP, 2013. Disponível em:

http://lemad.fflch.usp.br/sites/lemad.fflch.usp.br/files/2018-04/Lemad-DHUSP_Caminhos_da_Liberdade.pdf. 


\section{Bibliografia}

ALMEIDA, Leandro Antonio de. Projeto do Laboratório de Ensino de História do Recôncavo da Bahia (LEHRB). Cachoeira, 2009.

Produção de livros didáticos no mestrado profissional de História: relato de experiência a partir de uma disciplina da UFRB. Revista História Hoje, v. 5, nº 9, 2016, p. 221-248. Disponível em: https://rhhj.anpuh.org/RHHJ/article/view/228/176. Acesso em: 04 abr. 2020.

ALMEIDA, Leandro Antonio de. Parâmetros de produção e avaliação de materiais didáticos no Mestrado Profissional de História. Métis: revista de história e cultura, v. 16, n. 31, p. 19-46, 2017. Disponível em: http://www.ucs.br/etc/revistas/index.php/metis/article/view/5335. Acesso em: 04 abr. 2020.

ALVES, Ronaldo Cardoso. Entre Expectativas e Experiências: a gênese do Laboratório de Estudos e Pesquisas em Didática da História (LEPEDIH) da Unesp/Assis. História \& Ensino, Londrina, v. 21, n. 2, jul./dez. 2015, p. 235-264. Disponível em: http://www.uel.br/revistas/uel/index.php/histensino/article/view/23860. Acesso em: 04 abr. 2020.

BITTENCOURT, Circe. Ensino de História: Fundamentos e Métodos. São Paulo: Cortez, 2008.

CAINELLI, Marlene et al. Laboratório de Ensino de História: desafios de repensar a formação continuada de professores. História \& Ensino, Londrina, v. 11, jul. 2005, p. 153-158.

GIACOMONI, Marcelo P. et alii. Laboratórios de Ensino de História: refletindo e construindo com professores. OPSIS, Catalão, v.15, n. 1, 2015, p. 164-178. Disponível em https://www.revistas.ufg.br/Opsis/article/view/34722. Acesso em: 04 abr. 2020.

JESUS, Nauk Maria de; PERLI, Fernando. A Produção de Lugares na Formação Docente: experiências no Laboratório de Ensino de História da UFGD. História e Ensino. Londrina. PR. v. 21. n. 2, p. 209-234, 2015.

LOPES, Danilo Eiji. História dos Estudos do Meio: um estudo sobre as práticas extramuros da escola em São Paulo. Dissertação (Mestrado) em História Social, Faculdade de Filosofia, Letras e Ciências Humanas, USP, São Paulo, 2014.

MARIN, Marilú Favarin Relação teoria e prática na formação de professores de história: experiências de laboratórios de ensino no Brasil e da Associação de Professores de História em Portugal (1980-2010). Tese (Doutorado em Educação, UFPR, Curitiba, 2013.

MONTEIRO, Ana Maria. Professores de História: entre saberes e práticas. Rio de Janeiro: Mauad X, 2007. 
NÓVOA, Antonio. O regresso dos professores. Pinhais: Melo, 2011.

SOUZA, Rogério Santos. Relatório Final da produção do material didático do projeto descolonizando as narrativas históricas na educação infantil de Maragogipe-BA: contação de histórias como mecanismo de (re)significação da identidade étnico-racial. Dissertação (Mestrado Profissional em História da África, da Diáspora e dos Povos Indígenas), Cachoeira, BA, 2017c.

TARDIFF, Maurice. Saberes docentes e formação profissional. Petrópolis: Vozes, 2010.

\section{Sites}

Carta Educação - http://www.cartaeducacao.com.br/. Acesso em: 28 abr. 2019.

LAHIGE-UESC. http://www.uesc.br/nucleos/lahige/. Acesso em: 04 abr. 2020.

LEHRB-UFRB. https://www3.ufrb.edu.br/lehrb/. Acesso em: 04 abr. 2020.

LEHRB (Página do Facebook). https://www.facebook.com/Laboratório-de-Ensino-deHistória-do-Recôncavo-da-Bahia-LEHRB-241514672661795/. Acesso em: 04 abr. 2020.

Mestrado Profissional em História da África, da Diáspora e dos Povos Indígenas http://www.ufrb.edu.br/mphistoria/ . Acesso em: 04 abr. 2020.

LEMAD-USP. http://lemad.fflch.usp.br/ . Acesso em: 04 abr. 2020. 